\title{
Islamic Fanaticism in Indonesia and Malaysia as Seen Through the Lens of Online Comics and Memes
}

\author{
Dhany Putra Pratama ${ }^{1}$
}

\author{
${ }^{1}$ Universitas Muhammadiyah Yogyakarta \\ ${ }^{*}$ Corresponding author. Email: dhanyputra.026@gmail.com
}

\begin{abstract}
This paper investigates how online comics and memes view Islamic fanaticism in Indonesia and Malaysia. There has been a rise in Islamic fanaticism in Indonesian and Malaysian societies. Online comics and memes have also grown in these cultures and they represent new media for the expression and interpretation of daily events. These media are deliberately utilized to critique viral phenomena, ideas, and ideologies in a manner that the public considers both "funny" and "insulting." It is believed that the creators of digital comics and memes criticize the fundamental values of people without hesitation and satirize religion, ethnicity, race, and politics. This paper examines the rise of political and religious memes to argue that Islamic fanaticism is viewed by online comic and meme creators as a bigoted interpretation of Islam by radicals who desire to fulfill their personal needs. Such fanatics Islamists exploit hoaxes and disinformation to spread their ideas of religion to the public and in the process, taint the value of Islam.
\end{abstract}

Keywords: Fanaticism, Indonesia, Islam, Malaysia, Meme, Online Comic, Religion

\section{INRODUCTION}

The digital network of social media allows people to interact with other individuals or communities via the Internet (Teruelle, 2011). This network has become a major part of human life since the drive to globalization was initiated. Social media has become a platform through which individuals share their personal experiences and the experiential knowledge of their surroundings to the world without physical and constitutional restrictions or boundaries. People often connect with distant relations or new contacts on such online forums. The social media network also offers those seeking fame, recognition, and support a space where they can attract an audience, create a fan following, and influence citizens of the Internet world (netizen). For some people, social media transforms into a business domain in which vendors can advertise their products and reach consumers across the globe without having to buy expensive conventional advertising in the physical world. In short, social media has become both an extension and a representation of real life.

In this context, the term "representation" refers to the image of a person or a group as seen on social media through the power of becoming "viral" (Hudson, 2019). When real-life occurrences gain widespread attention, usually through information sharing on social media, the phenomenon is known as viral news. Viral posts gain popularity either on their own or after memes are created as interpretations of the original post. In simple terms, memes refer to the joke versions of real-life events, cultural symbols, and social ideas, usually in the form of pictures and videos. The meaning of memes can either be "very deep" or "very obvious" (Gil, 2019). The cartoon, an evolved version of the old-fashioned comic strip, is another online form of ironic self-expression. In its digital form, the cartoon is still as popular as the newborn meme.

Since the use of social media became widespread, numerous meme and comic creators began posting their work online to comment on various aspects of human lives. Social, political, and historical news have been popular subjects of memes since the inception of this form of commentary. Accounts are created where meme-makers post their opinions in the form of obvious, philosophical, satirical, dark, or insulting jokes. Religion is one such topic that is often made the subject of jokes. Despite the potential of controversies resulting from such jest being considered blasphemous to the religions in question, there are people who enjoy the jokes as "the truth." 
Recent years have witnessed a worldwide increase in the intensity of "ethnic, racial, and religious fanaticism," an obsessive devotion to a certain identity displayed through the words and actions of a community. For instance, the United States is waging war against rightwing supremacists who demand an all-white, allChristian nation (Blow, 2019). The same sentiments are shared by other regions of the world where people of Caucasian descent are in the majority. On the other hand, Asia is under the siege of Islamic fanaticism, especially in countries such as Indonesia (Fitriyah, 2016) and Malaysia (Tan, 2017) that demand the orthodox and "complete" implementation of Islamic ideology, which threatens the pluralism of both nations. This trend toward fanaticism is attracting mass attention and it has become impossible to overlook the news coverage and public discourse regarding its existence, goals, and impact on the social landscapes of Indonesia and Malaysia. Online comics and memes eventually participate in this mass discussion but choose to do so in a rather peculiar manner.

\section{RESEARCH QUESTION}

This paper will attempt to answer the question, "How do memes and online comics describe Islamic fanaticism in Indonesia and Malaysia?"

\section{LITERATURE REVIEW}

Religion is an ancient institution that dates back to the existence of civilizations. Meme culture, on the other hand, is a new phenomenon that is a product of globalization and technological development. Memes deviate from the traditional view of religion as sacred and perceive creeds in unusual and jesting ways.

\subsection{Religious Fanaticism in History}

Religion is a unified belief system based on sacred values and practices (Durkheim, 1915). Organized religions have been a major part of human life for millennia. Essentially, religion is meant to unite various groups that may be separated by racial, ethnic, and geographical differences through the establishment of one belief system. Religion subscribes to the existence of a certain power that is assumed to control the universe and that is beyond the recognition of the mortal sensory realm. Individuals within a religious group are bound to certain norms and regulations that differ from religion to another, but that also evince several fundamental similarities. At its core, all religion defines the "rights and wrongs" of human actions (Dennett, 1998). However, while there is a massive following for this social institution, there is also a growing stigma surrounding it. Ideas are known for their sheer ability to adapt to ensure their own survival instead of the existence of human beings. Nonetheless, religion is probably the most maladaptive of ideas conceived by human beings (Bulbulia, 2008) because of the rigidity and orthodoxy of the religious system and because of its biologically irrational bases. However, Dennett (1998) argues that like any other idea that distinguishes humans from all the other species on the planet, religion has its own formula of evolution.

With the birth of civilizations are born religions, and as civilizations differ from one another, so do religions. History has often found religions fighting "holy wars" or "crusades" against each other to gain power. Holy wars are fought for a particular religion to become the sole system when one civilization views others as threats to its existence due to differences in values, and when a particular civilization fears that the values of other cultures may replace its own (Huntington, 1996). In contemporary times, such religious crusades are fought through the modern form of hostility or "religious fanaticism." This type of human behavior idolizes a certain religion and simultaneously regards others as inferior. While some religions are identified as fanatical, as Voltaire described Islam (Colas, 1997), fanaticism may also result from a very human condition: it "redoubles" people's "effort when they have forgotten their aim" (Santayana, 1905). It is ironic that despite the massive development of information technology which was promoted to increase human quality in many sectors, fanaticism continues to grow in society using the same media that was purposed to erase it.

\subsection{Religious Memes: A League of Their Own}

Burroughs and Feller (2015) encourage religious memes to be "viewed on their own terms" and as "able to differ in substantive ways from normative iterations of popular culture memes" by scholars. They are unique despite essentially being memes. Placing pop-culture memes and those that are religious in nature in the same category may cause the misconception of either the joke or the misleading of religious values articulated by the memes. If the two forms of memes are conflated, the public would fail to understand the intended meaning of religious memes; unnecessary damage would be caused to religious values and to the main mission of all religions: spreading the message of peace and positivity.

Several religious groups have considered using social media to spread religious values as constructively as possible. One such case is mentioned in an article written by Burroughs and Feller (2015). It concerns the Church of Jesus Christ of Latter-day Saints (LDS) in which the prophet (the president of LDS church) is said to be called by God to guide followers to "sweep the Earth" with the positivity of the church via digital spaces, uniting technology and tradition. Similar movements have taken place in several parts of the 
world, including in Indonesia and Malaysia, which are the main focus of this paper. Facebook pages such as Meme Comic Islam (Meme Comic Islam, n.d.) and meme.malaysia (meme.malaysia, n.d.) are two examples of the large community of religion-based meme accounts in the two countries in question. These online agents attempt to disseminate the positive values of religions, especially Islam, through social media.

Burroughs and Feller (2015) also argue that lately the Internet is becoming filled with anti memes: critiques toward a religion displayed within the same domain in which religious memes are produced. The existence of anti memes can be identified through their tendency of presenting either subtle humor or blatant hostility toward religious teachings. The ant-memes thus ignite resentment in many people, and are described as "tending to be more atheistic than religious." They are often confused with memes because they coexist within the same space and represent the same values (religious practices, understanding, etc.), only through a different perspective.

\subsection{Islam in Indonesia and Malaysia: Political and Religious Domination Combined}

Southeast Asia was once a major medieval trading route connecting the whole continent of Asia (East, South, Middle East, etc.), Africa, and Europe as it does even today. Thus, this region became the breeding ground of various world-recognized religions: Hinduism, Buddhism, Islam, Christianity, Catholic, and Confucianism. It is argued that the current civilization of the region is shaped through the coexistence of these religions (Madinier, 2011) in the local people along with their indigenous belief systems. Over the years, these "foreign" religions gradually gained massive favor from the locals, who converted themselves into one of the many available religions. Eventually, the indigenous base declined and local beliefs almost became extinct. These six religions are now found to be popular in society while indigenous beliefs are limited to village communities or tribal groups residing in forests.

Despite their coexistence, these six religions are caught in a constant struggle of seeking followers and attaining control over the values applied in larger society. Islam is one of the most dominating religions in Southeast Asia and is especially prevalent in Indonesia and Malaysia. In fact, 87.18 percent of Indonesia's total population and 60.4 percent of Malaysians are Muslims (Pariona, 2018). In fact, Indonesian and Malaysian societies are greatly influenced by Islamic values due to the rise of Islam as the majority religion. One such aspect that has felt the impact of Islam is the political environment of both countries.

In Malaysia, the ascendance of the United Malays National Organization (UMNO) as the dominant political party in 1969 triggered the Malay-Islamic political dominance. It is a system that greatly favors Malay-Muslim personalities and represses non-Malay and non-Muslim political, economic, cultural, and religious influence and rights. Consequently, the democratic system of Malaysia's politics developed extensive applications of Sharia law in almost every aspect of citizens' life (sexuality, clothing, patriarchy, and women's rights) and restrictions were imposed on the norms of other faiths (religious buildings, languages used in Bible and other Christian publications, conversion from Islam, inter-religion marriage dispute) (Mohamad, 2011). Indonesia, on the other hand, displays a rather nonsystematic shift and introduced the total application of Islamic law. Islam was the weapon utilized to ignite feelings of nationalism during the war against European colonial powers, which were identified by their Christian belief (Picard, 2011). Regrettably, Islam is itself currently identified by waves of violence and is perceived in Indonesia as a negative entity that seeks dominance in the nation's political and religious realms. Historically, the struggle of pro-Islam movements to establish Islamic values of Sharia in Indonesia can be traced back to the proposal to impose "Ketuhanan dengan menjalankan syariat Islam bagi pemeluk-pemeluknya" as a point of both Piagam Jakarta and Pancasila. These sentiments formed the basic constitution of Indonesia during the proclamation era in 1945 and were later replaced by "Ketuhanan Yang Maha Esa" as the first principle. The years that followed displayed growing dissent toward the Soekarno government that eventually preferred a secular and republican model of Indonesia. This notion was vigorously opposed by Muslim political powers (Hasan, 2011).

The twenty-first century once again witnessed a rise in Islamic fanaticism in various parts of the world, including Indonesia. The most extreme form of Islam is presumably represented by terrorist actions, as marked by the Bali bombing of 2002 (Ridwan, 2018) to establish a Sharia-based Indonesia and to condemn the current political system of the time as thaghut, an Islamic term referring to the worship of anyone besides Allah/God or actions that willingly contradict Allah and Islam. Every Muslim is obliged to wage war against it. Ironically, thaghut is often radically interpreted as, "everything that does not belong to Islam" and has been politicized to discredit every system that does not implement Sharia law (often simplified as khilafah) and every person working under that system, despite being Muslim. Unfortunately, instead of losing influence over its violent interpretation of Islamic teachings, the Indonesian government faces more severe problems. This perspective has gained public favor by influencing societies through the gaps missed by the government in schools, both public and private (ironically, funded by Saudi Arabia) (von Hein, 2017). In addition, hardline 
Islamist movements such as the Islamic Defenders Front (Front Pembela Islam) and the Hizbut Tahrir continuously voice demands for a caliphate to be formed in Indonesia to replace the existing constitution and moral principles, the Pancasila, and UUD 1945 (Kurlantzick, 2018). Even the notorious Islamic State of Iraq and the Levant (ISIL/ISIS/IS) and its allies consider Indonesia to be one of their recruitment bases and regard all of Asia as their new "battleground" (Chellaney, 2019). Lately, these hardline movements are suspected to have been a party to the coalition of Prabowo Subianto, an ex-Indonesian military special forces general and a contender in both the the 2014 and 2019 Presidential Elections against the incumbent President Joko "Jokowi" Widodo. Indonesia experienced an increase in antigovernment demonstrations between 2014 and 2019. These protests are often driven by the rhetoric that Jokowi's administration is attempting to repress Islam's presence and influence. The latest demonstration took place on May 21 and 222019 because of the suspicion that President Jokowi cheated in the 2019 elections. The Election Supervision Bureau or Bawaslu was under siege when the protests turned violent around midnight (CNN Indonesia, 2019).

Malaysia, Indonesia's neighbor and another Muslim majority in Asia, also faces identical problems. It is another recruitment post for ISIS and its allies who desire to fight their holy wars in Asia and the Middle East. The fanaticism in Malaysia is arguably growing at the same rate as it is in Indonesia (Kurlantzick, 2018). Nevertheless, the growth of Islamic fanaticism in Malaysia is more systematic and more ethnic-backed in comparison to Indonesia. The Malay ethnic majority is predominantly Muslim and there is a growing belief within the group to maintain both Islam and Malayaffiliated entities as the major power of Malaysia. In fact, the position of the majority identity was secured at the national scale following the 1969 Malay-Chinese interrace riots in Kuala Lumpur (Liow \& Tan, 2019). The 812 protests in 2018 demanded that Prime Minister Mahathir Mohamad should not ratify the International Convention on the Elimination of All Forms of Racial Discrimination or ICERD. The protesters feared the threat posed by such a subscription to the domination of the Malay identity and the revocation of the privileges Malays had enjoyed for decades. Such protests represent the most recent examples of the Malay-Muslim power domination of Malaysia. In addition, the abovementioned demonstration was backed by the UMNO and Partai Islam Se-Malaysia (PAS) who were among the parties who lost the May 2018 elections to the Pakatan Harapan coalition that supports Mahathir Mohamad and the other thirty percent of the voices of the Chinese and Indian minorities (Wijaya, 2018).

\section{THEORETICAL FRAMEWORK AND METHODOLOGY}

This paper will examine Islamic fanaticism in Indonesia and Malaysia through memes. Memes are a recently developed form of expression, and the paper will focus specifically on those that evidence a distinctively political and religious nature.

\subsection{Memes to Movements: The Rise of Political and Religious Memes}

A Xiao Mina's Memes to Movements: How the World's Most Viral Media is Changing Social Protest and Power discusses the trend of rising movements on social media and examines the advocates of the freedom of expression on the Internet, especially in the US and in China. In the book, Mina (2019) quotes a scholar, Tim $\mathrm{Wu}$, as saying that "technology does not follow culture so much as culture follows technology. New forms of expression naturally arise from new media, but so do new sensibilities and new behaviors." Using this argument, one can assume that memes indicate a new set of behavior projecting freedom of expression and resulting from the development of information technology. To combat the strict control wielded by authorities over the Internet, the advocates of certain ideas attempt to attract public attention by devising new methods that are able to "slip" through government controls and restraints. Memes are currently the accepted form of expression of those desiring to reach mass audiences. They are essentially sets of pictures that illustrate real events in a humorous manner. They are posted on social media and are shared by multiple users on the platform. Thus, they gain popularity at rapid speeds, and now thousands of users online are creating a flood of pictures branded as memes.

Memes are currently one of the most popular methods of expression in the world, but the critiques against meme culture have been harsh. Nicholas Demas "congratulates" the Internet for "giving birth to an innovative method of being offensive" (Mina, 2019). Memes are created on a variety of subjects, and the categories that are currently on the rise are political and religious memes.

Wiggins' The Discursive Power of Memes in Digital Culture: Ideology, Semiotics, and Intertextuality considers political memes to be a sub-genre of the larger category, often used to address specific political philosophies and ideologies (Wiggins, 2019). On occasion, these memes also represent certain political events in history, both past and present. Wiggins also provides a definition of meme based on the argument of Raymond Williams that a meme is a "culture" intentionally produced by people by introducing sets of behaviors, texts, and other forms of expression in all 
aspects of human life. The political culture of current society indeed grows in alignment with the development of technology. As a sub-category of the genre, religious memes address spiritual beliefs, practices, and manners. However, Burroughs and Feller (2015) contend that religious memes must be distinguished from popular cultural memes because of their potentially substantive differences. Throughout history, religion has been a sacred theme for civilizations across the globe and societies attempt to avoid misinterpretations of religion that can result in accidental or incidental blasphemy.

However, both political and religious memes are caused by the dynamic nature of human culture and are the product of the learning process of humankind as it adapts to transformations imposed by changing times. The methods used to disseminate ideas also adapt to changes occurring in society in order to maintain the existence and popularity of certain political and religious beliefs. In turn, the ideas also adapt to social modifications that occur through time and utilize every invented media to disseminate their messages.

\subsection{Research Method}

Qualitative methods of analysis were utilized for this study, which aimed to investigate memes on Islamic fanaticism in Indonesia and Malaysia. The investigation used secondary data in the form of books, journal and online articles, news, and posts of related social media accounts to answer the research question.

\section{DISCUSSION}

In the middle of various events indicating religious and ethnic tensions throughout the Malacca straitsituated Malaysia and the archipelagic islands of Indonesia, communities sprang up to voice their opinions in rather unusual and sometimes unethical ways. In so doing, they provided the public with insights into every social problem through images and other kinds of expressive media. Working under the same principle as the caricature often seen in classic and modern day newspapers, an exaggerated form of news and figures related to it are pictured as funny rather than a form of articulation to be taken seriously.

\subsection{Islamic Memes: Forms of Positive Teachings}

$D a$ 'wah or dakwah or the spreading of Islamic tenets to the world is mandated for every Muslim regardless of gender, age, and social status. It is, in fact, mentioned in both the Holy Quran and in the Hadits (sayings of Prophet Muhammad PBUH) as below:

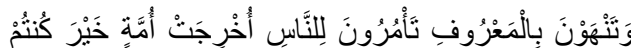

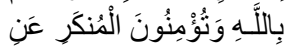

You are the best community that ever emerged for humanity: you advocate what is moral, and forbid what is immoral, and believe in God. (3:110)

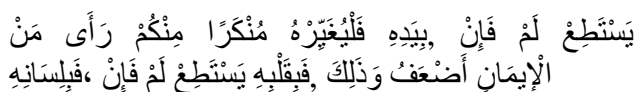

Whoever among you sees the evil, he should change with his hand, if he should not change it with his oral, if it cannot be with his heart, and that is the weakest of faith (Muslim: 49)

In this context, Religious memes are intended to deliver the message of God (Burroughs \& Feller, 2015) to the public, which is essentially dakwah in Islam. Interpreting both the Quranic verse and the Hadith above, it is permissible to spread the teachings of Islam via various media (i.e., speeches, articles, attitudes, etc.) as long as it causes no harm to society (i.e., coercion, war, terror, etc.); memes are among these media.

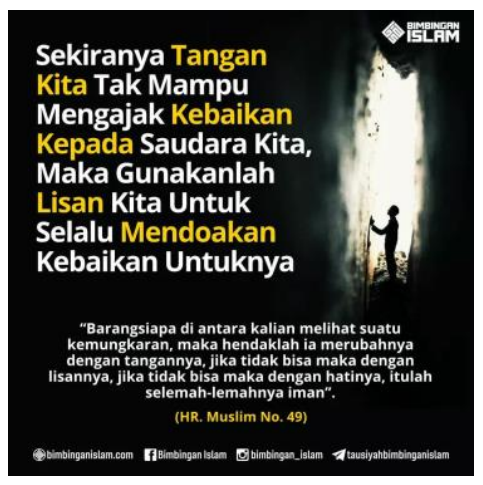

Figure 1 Reminder of Dakwah (Meme Islam Indonesia, 2017).

Indonesian citizens often describe this community as akun dakwah, comprising social media accounts and pages dedicated to delivering the teachings of Islam. These accounts serve as "reminders" for Muslims to remain true to the faith of Islam and as cautions against deviating from the teachings of Allah and the Prophet. In addition, these accounts also serve as indirect invitations for anyone willing to learn and to embrace Islam by teaching its basic principles and manners according to the Quran, the Hadith, and words of the religious experts or "ulama." 


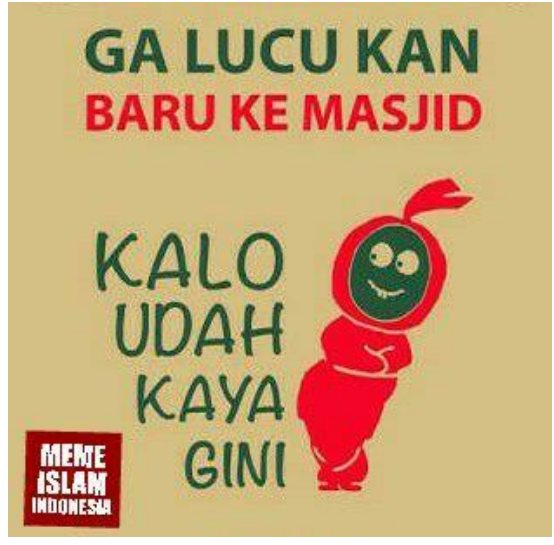

Figure 2 Reminder to Follow the Five Prayer Times (Meme Islam Indonesia, 2017).

Fajar : Increase Beauty

\section{Zuhar: Increase Income}

Asar : Improve Health

Maghrib : Release Tension ()

Esha : Peaceful Sleep

\section{(1)/ For More : Offer Tahaijud}

Figure 3 List of "Benefits" of Praying Five Times Daily (SL Muslim Memes, 2019).

\subsection{Islamic Memes: Islam Against the "World"?}

Following the 9/11 incident in 2001 and the various civil wars in the Middle East, the religion of Islam, as well as the Muslim community, faced backlash in the form of negative commentaries, discrimination, and violence, all of which added to the intensely growing global negativity toward Islam. Further, Western media's bias on the reporting of terrorism adds more fuel to the already raging fire of Islamophobia, escalating the interreligion, intercommunity tension to an alarming level (Gallup, n.d.).

Several issues are believed to cause the rising tensions between Muslim communities and the dominating, widespread Western liberal values. Among them is the perception that Islamic views indicate strong condemnation of popular liberal concepts such as feminism and the LGBT community. Often, Muslims are thus scrutinized by the rest of the world. Due to this perception, anti Muslim and anti-Islam memes igniting intercommunity hatred toward Muslims are also rampant on social media platforms. In another issue, the fanaticism/extremism of several other religions and racial supremacist movements targeting "outsiders" and "infidels" are also on the rise. Muslims and Islam are suspected to be the most distinct of all among the people who possess distinct differences with their identities and ideas. It is often discovered that Muslim-targeted violence is experienced by those of Middle Eastern descent in the United States (Beydoun, 2018), Europe, and Australia (Al Jazeera, 2019), as also in the case of the Rohingya descendants of Myanmar (Roughneen, 2017).

\section{If you liked the Nike ${ }^{\mathrm{TM}}$ Hijab...}

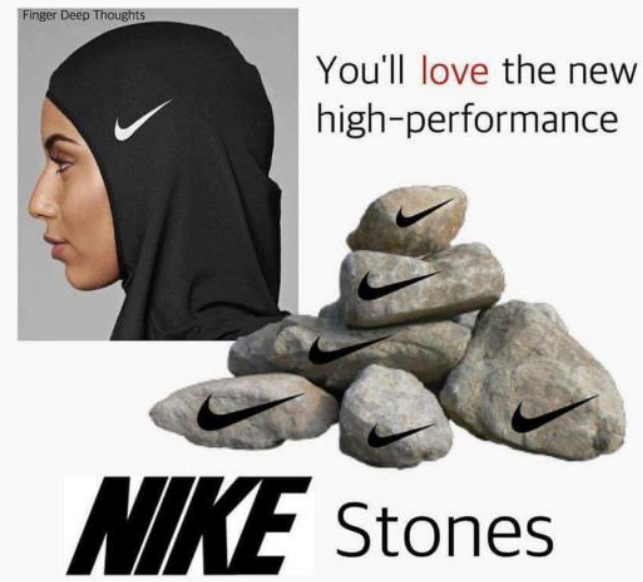

For when she takes it off.

Figure 4 Meme on the Punishment for Removing Hijab (Dopesmoker, 2017).

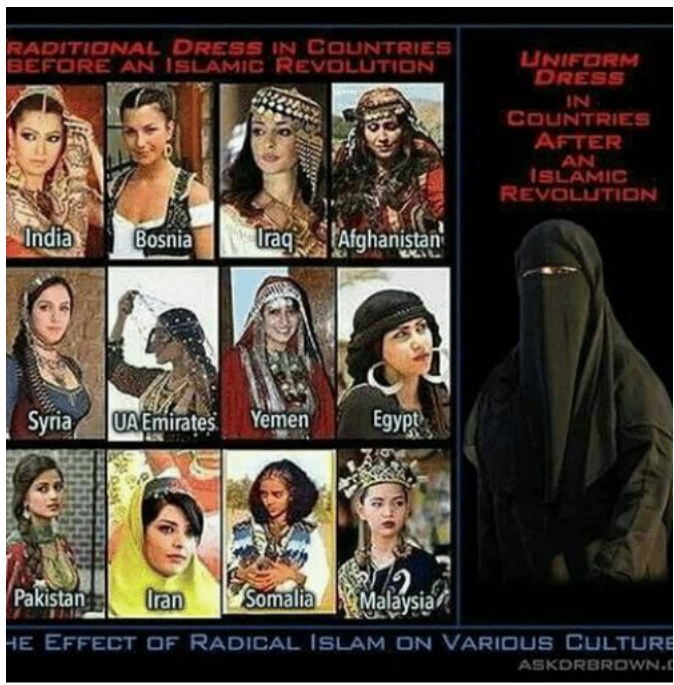

This was your culture. This is your culture now on Radicallslam. Any questions?...
IslamicInvasion Caliphate

Figure 5 Meme on Niqab replacing Traditional Dresses (Me.me, 2017). 
Due to multiple reasons, there are numerous movements against the presence of Muslims. The popular belief is not only that Islam is among the strictest of all faiths, but also that the religion encourages its followers to disseminate its teachings by any means necessary (including violence). In reality, the political agendas of certain politicians are worsening the misunderstanding of Islam in several countries. Today, supremacist groups include Muslims as their main targets of "cleansing" (the most recent one being the Christchurch Mosque Shooting in March 2019) (Al Jazeera, 2019).

\subsection{Islamic Memes: Islamic Fanaticism in Indonesia}

Muslims around the world have to swallow a bitter pill on a daily basis, knowing that there is a sense of hatred in society against them caused by the misunderstanding of Islamic teachings by non-Muslims and radicals. Muslim fanatics have made the situation worse by displaying the misinterpretation of the very religion in which they believe. These groups are often observed in public conducting dakwah in a rather unfriendly manner, either by coercing people or by turning violent when their "message" is ignored or rejected.

Indonesia's issue with Islamic fanaticism becomes more difficult in congruence with the growth of global terrorism and continues to gain global attention at a rapid scale. For example, Indonesia's Front Pembela Islam (FPI) is among the notorious examples of how often Islamic teachings are interpreted and practiced through violent methods. The organization often receives harsh criticism from moderate Muslim communities (Bisyir, 2019) for disturbing the public order and for promoting the practice of radicalism. Cases involving FPI include the assault on a 15-year-old Chinese boy for insulting the group on social media (Roughneen, 2017), the Aksi Damai 212 rally demanding the arrest of former Jakarta incumbent governor, Basuki Tjahaja Purnama or Ahok, in 2016 for religious blasphemy against Islam while promoting anti Chinese and anti Christian sentiments (Robinson \& Roughneen, 2017). It is undeniable that this organization has repeatedly represented Islam in an unfavorable way. Another Islamic organization receiving global renunciation is the Hizbut Tahrir, a hardline group that has established an agenda of establishing a global Islamic caliphate and that still works under the cover of various Islamic organizations as it is officially renounced in Indonesia (Saputra, 2019). Hizbut Tahrir Indonesia is among the most the influential of the extreme factions. It operates its own media and press office for the purpose of propaganda. Some articles from the HTI press releases are marked "antigovernment" because they challenge both the government and the constitution (Pancasila and UUD 1945) (Durohman, F., \& Rizal, 2017).

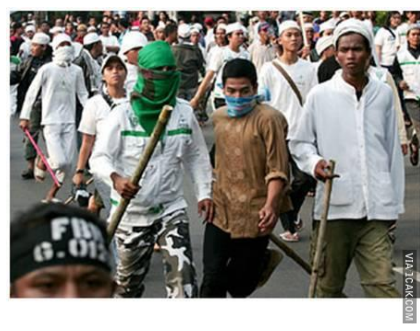

\section{GANGSTER BERKEDOK ORMAS ISLAM}

Figure 6 Meme on Niqab replacing Traditional Dresses (Me.me, 2017)

Prior to the Aksi Damai 212 rally of December 2, 2016, and immediately after, several akun dakwah bombarded the Internet with propaganda condemning the election of non-Muslim leaders, directly referring to Ahok as the only non-Muslim candidate in the 2017 Jakarta Governor Election. This propaganda greatly diminished Ahok's chances of obtaining votes in the election and at the same time, increased his contender's chances by rocketing his number of voters. Thus, Anies Baswedan was the remaining Muslim candidate following the defeat of Agus Harimurti Yudhoyono at the first voting round. It is unfortunate that this movement was not merely focused in Jakarta; instead, it spread across Indonesia with banners reproving nonMuslim candidates displayed in several cities (Susetio, 2018). In addition to the anti pemimpin kafir (anti infidel leaders) movement, the rhetoric of the rise of communism was replayed in the 2014 Presidential Election, as illustrated by a post of an akun dakwah:

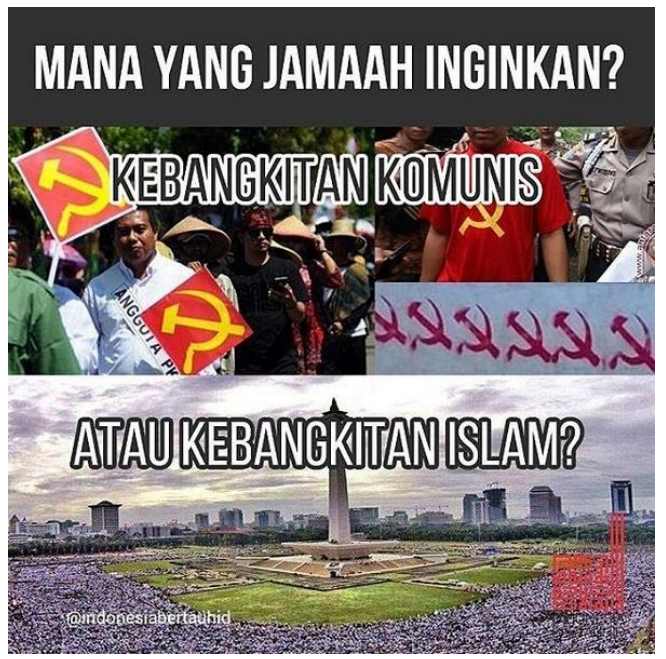

Figure 7 "Akun Dakwah"s Post on the Rise of Islam (Indonesia Bertauhid, 2016) 
Perceiving the violent nature of Islamic fanaticism, voices of rejection of Islamic radicalism/fanaticism have been popularized not only by non-Muslims, but also by Muslims who refuse to be included into the group that is publicly "tainting" the name of Islam and of Muslims. Critics of radical Islam come from many backgrounds, and include religious and public figures, artists, and ordinary civilians who are offended by the behavior of fanatics. Often, they deliberately express their ideas through art and through other forms of expression, referring to real events involving these groups and often humiliating them. The messages are clear: "Display of Stupidity" and "We Are Not One of Them."

In Indonesia, the centuries-old anti Chinese sentiment has worsened because of the New Order's paranoia toward Partai Komunis Indonesia (Indonesian Communist Party). The Chinese are stigmatized as anti Islam, atheistic, inhumane, and "backed by the communist Chinese government." Surprisingly, this sentiment still obtains massive popularity and support from several Indonesian communities. Recently, there was a flow of fake news (hoaxes) across the Internet regarding Joko Widodo's "affiliation" with the Chinese government and accusing the incumbent president of selling out the country (Chew, 2019). This paranoia grew to the extent that the race became identified with religious and political perspectives (Chinese identities are frequently oversimply branded as either "Christians" or "communists") and this meme below may explain the situation.

\section{"China apa Islam?"}

$$
\begin{aligned}
& \text { "Ya Islam.” } \\
& \text { "Oh udah masuk Islam?" } \\
& \text { "Iya, tapi ya China." } \\
& \text { "Tapi kok masih China? }
\end{aligned}
$$

Figure 8 Meme on Identity Branding (Mountaine, 2019).

In the realm of the Internet, Indonesia's Cebong VS Kampret social media warfare has been an eye-catching and vulgar display of fanaticism by both Joko Widodo's and Prabowo Subianto's supporters. This strife indicates that religion and race play major roles in the accumulation of supporters; it also indicates that hardline movements are persevering. The online warfare grew more intense following the 2017 Jakarta Governor Election and the 2019 Presidential Election with fake news attacking the candidates of the elections spread both via mainstream social media (i.e., Facebook,
Twitter, Instagram, etc.) and through private messaging platforms (i.e., WhatsApp) as well as video hosting sites (i.e., YouTube). As a result, people were "corrupted" (BBC News Indonesia, 2019) into believing the falsehoods. Additionally, in terms of the role of religious figures and their teachings, their political affiliations appear to influence their followers; some leaders are even willing to accuse each other of being "infidels" due to differing political allegiances, as illustrated by KOSTUM (Komik Strip Untuk Umum)

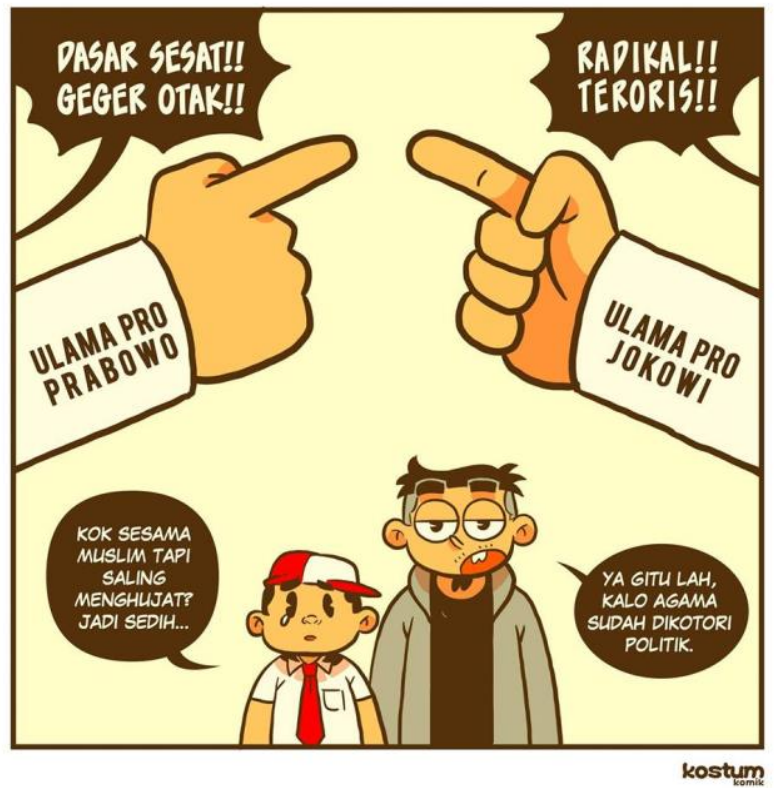

Figure 9 KOSTUM's Illustration of Political Conflicts between Ulama (KOSTUM, 2019).

The Christchurch mosque shooting in New Zealand in March 2019 was yet another event that reminded the world of the rise of hate groups seeking justification and support for their ill-intended actions under the name of racial and religious supremacy. Actions such as this debase global society through their endeavor for political populism (History, 2019) in the post-truth era (the time when society tends to and prefers to search for justification instead of truth) (Cahyono, 2018). The same happens in Indonesia as political groups seek support while discrediting their opponents by manipulating society through outdated, and sometimes baseless, but effective issues. For instance, the anti Chinese and anti infidel rhetorics are among the most popular, despite being repeatedly used for half a century. As communities across the globe expressed their grief after the Christchurch incident, several anti-immigrant movements celebrated the shooting incident as something the immigrants, mostly Muslims, deserved. In particular, former Australian Senator Fraser Anning, famous for his far-right, extreme anti-immigrant stance, blamed the incident on the victims. As resentment toward Anning grew, Will Connolly, a 17-year-old boy, cracked an egg on the senator's head, gaining 
worldwide fame and support as the "Egg Boy" (Farzan, 2019). The author of KOSTUM apparently observed a similarity in Anning's anti-immigrant ideas and the anti Chinese and anti infidel movements as religion and race-based hatred and "proposed" that the same action should be performed in Indonesia, as illustrated below:
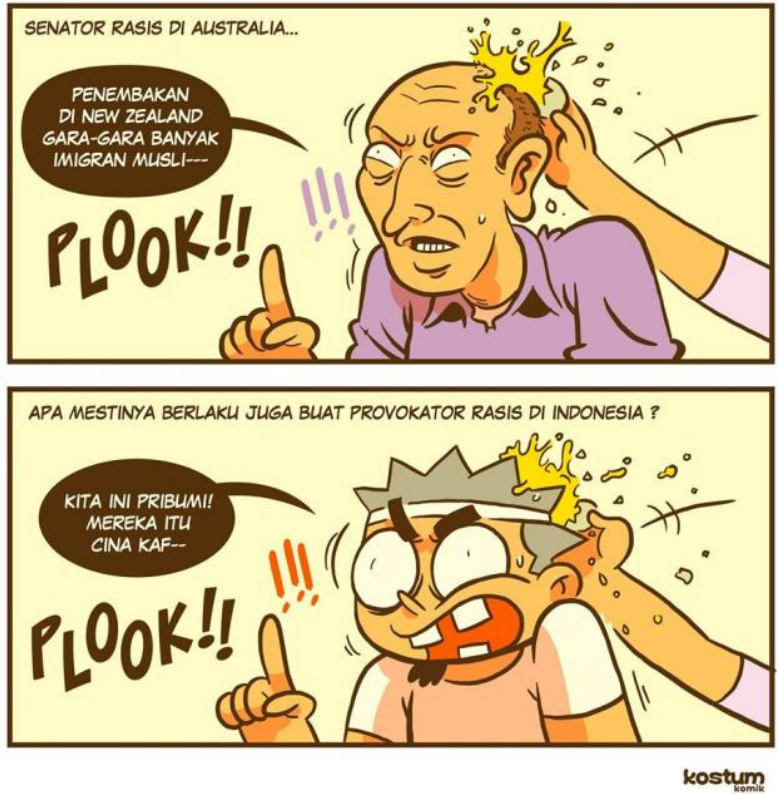

Figure 10 KOSTUM's Illustration of Racism in Indonesia (KOSTUM, 2019).

\subsection{Islamic Memes: Islamic Fanaticism in Malaysia}

Malaysia had always been the role model of Islamic moderatism and tolerance in Asia. However, the 1980s indicated a dire situation regarding radicalism with the rise of Islamic revivalism in the nation. Suddenly, there was an advocated voice for stricter and more intense control over the daily lives of Muslims (food, clothing, prayers, social interactions, etc.). This triggered separations not only among ethnic groups and religions residing in Malaysia, but also among Malay-Muslims. The Islamization process of Malaysia reached the peak with the control of PAS and UMNO constructing public policies in favor of "making better Muslims" (Syariah banking system, homing discount, monitoring of behavior/Akhlak, etc.) (Osman, 2016) Consequently, moderate Muslims and Malaysian minority groups often received backlash and humiliation from conservative groups in the country for simply "not being one of them." A specifically sensitive issue for Muslim communities includes the solidarity expressed by Malaysian Muslims with Palestine against Israeli occupation (Amnesty International, n.d.). At some point, several groups force a growing public "obligation" to support Palestine and those who do not participate in the movement are described as being unempathetic, which is what this meme illustrates:

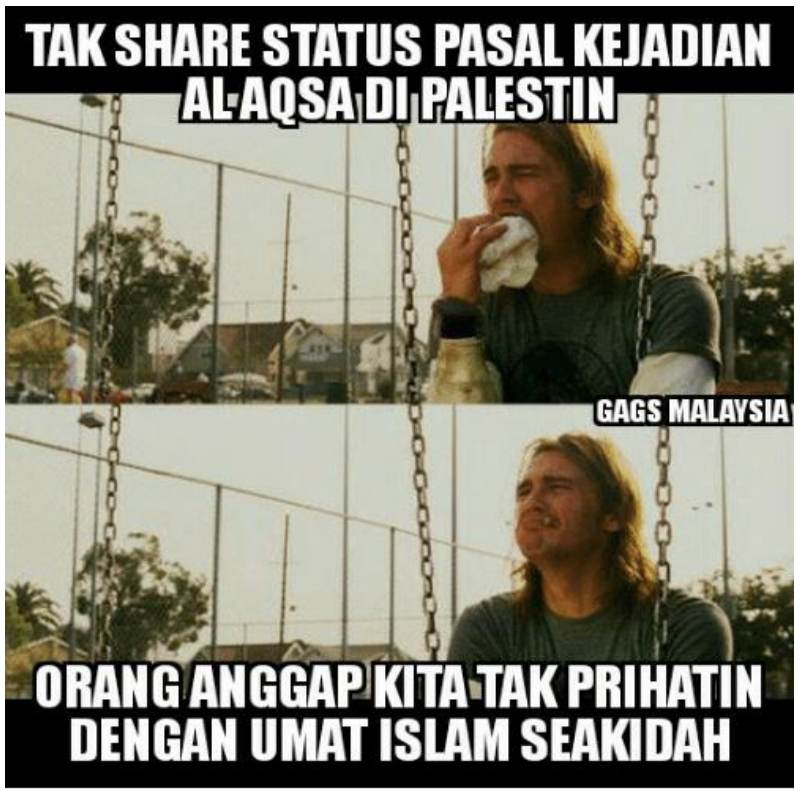

Figure 11 Meme on Not Participating in Palestine Campaign (Me.me, 2017).

Among all minority groups residing in Malaysia, presumably the most unfortunate is the Lesbian, Gay, Bisexual, Transgender, and Queer community (LGBTQ) because of the strict application of Islamic law. Most religious communities consider this group to be "deviant." However, Malaysia implements harsher treatments toward its LGBTQ citizens as their actions are deemed unlawful. Homosexuality is considered a crime and those caught committing it are caned and sentenced to jail (Reuters, 2019). More, along with the legal punishment, members of the LGBT community face rejection and resentment from Malaysian society. Muslims in the country are especially against the practice of homosexuality as same-sex intercourse is among one of Islam's major taboos, as explained in the Quran in a verse of Al-Ankabut:

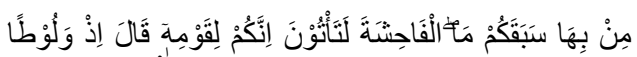

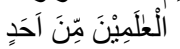

And Luth, when he said to his people, "You are committing an obscenity not perpetrated before you by anyone in the whole world." (29:28)

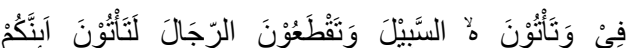

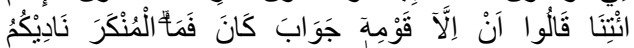

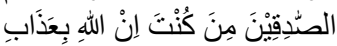

You approach men, and cut off the way, and commit lewdness in your gatherings." But the only response from his people was to say, "Bring upon us God's punishment, if you are truthful." (29:29) 
Voicing the experience of LGBTQ citizens in Malaysia, a cartoonist using the name alPantuni attempts to describe their condition through a series of comics as illustrated:
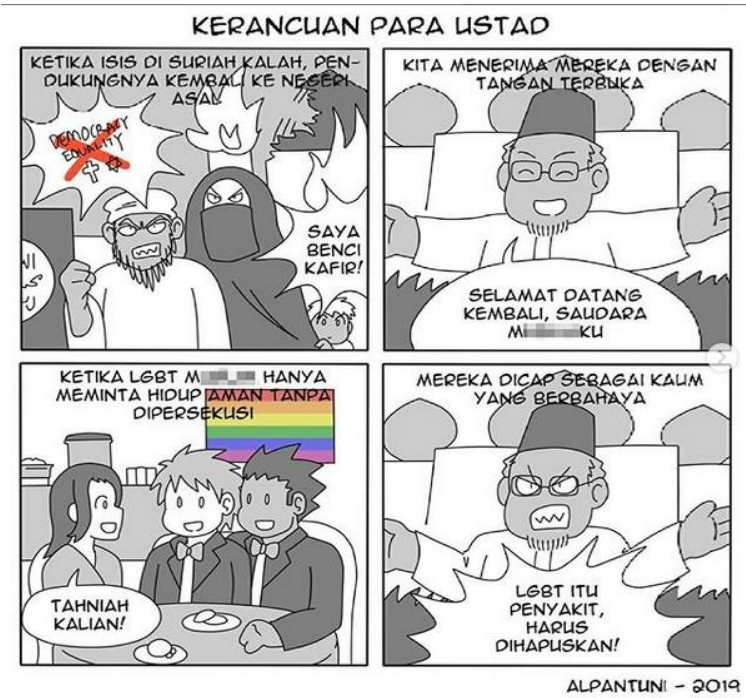

Figure 12 Comic by alPantuni describing Views in Malaysia on LGBTQ people (alPantuni, 2019)

In order to reject fanaticism, artists and meme creators rise to voice the concerns of those affected by Islamic extremism. For instance, as Ramadhan month passes by year-after-year, it is compulsory for Muslims around the world to learn and to practice their faith in a more vigorous manner than in regular months. They are obliged to fast, pray, and to donate at a more intense scale. However, several groups of people often fail to recall one element of fasting, to "manage the emotions." A Malaysian comic author named Vulpineninja expresses her concerns in one of her comic strips:

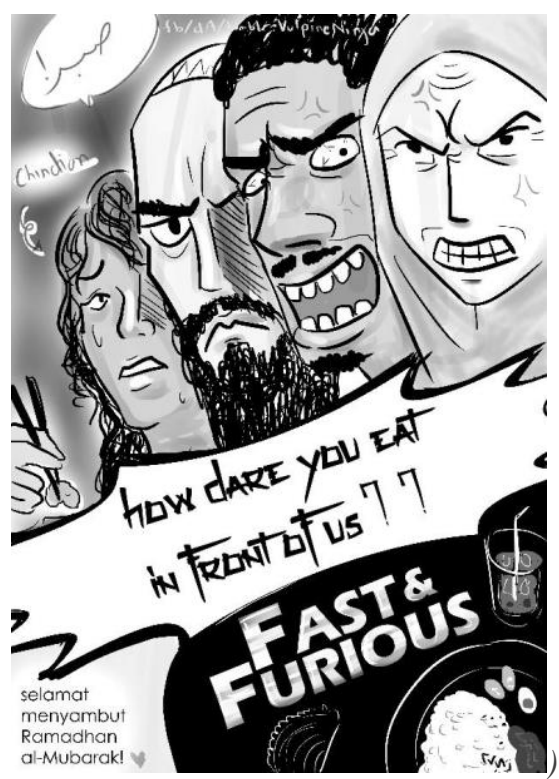

Figure 13 Comic by Vulpineninja on Ramadhan (Vulpineninja, Ramadhan baru je mula tapi aku masih nak cari pasal kan?, 2015)
Women's movement groups afflicted by patriarchal and religious conservatism often voice their apprehensions on the issue of the manner in which women's rights are revoked under the pretext of "religion" (Prakash, 2002). Malaysia experiences frequent cases of toxic patriarchy as conservative Islamic communities continue to preserve the idea that "women belong to the kitchen" (gaining subsequent support from other religious and ethnic-based patriarchal groups). Advocates of women rights have also started to voice their opinions through comics. An example is the following post by an anonymous author to author Vulpineninja:
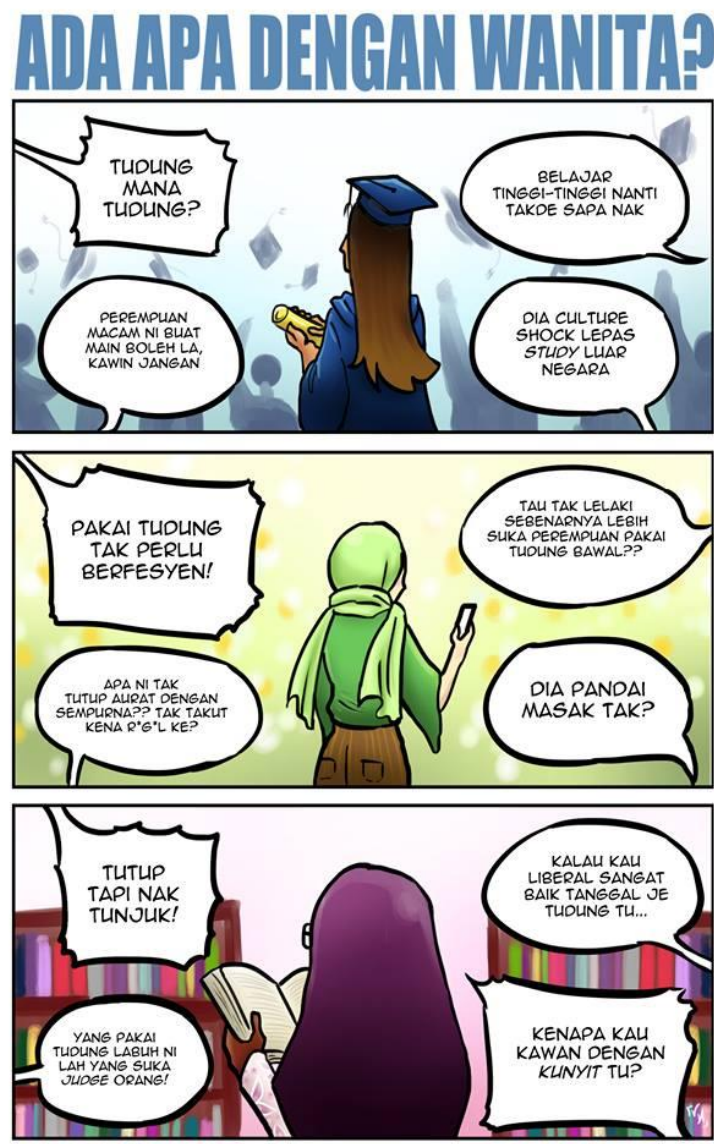

Figure 14 A Comic on Toxic Patriarchy and Misogyny (Vulpineninja, Commissioned by anonymous, 2019)

\section{ANALYSIS}

Observing the examples of online memes and comics already presented, it is notable that there are certain messages each meme and online comic creator intends to deliver to his/her audience, in this case Internet citizens (netizens). The purport of the messages differs according to their creators. 


\subsection{The Delivered Message of Satire}

Online comics and memes essentially become the medium of their creators who wish to create a satiric version of real-life events. They are intentionally created to ridicule and to condemn vise, folly, abuses, and evil of any kind. Such invective messages are always hidden under the notion of being purposed for entertainment but they comment on real issues that occur around a community by combining the elements of realism and fantasy in one story (Hodgart, 2010). The art of satire appears and prevails through the course of history and it continuously becomes the voice of critics with regard to social, political, cultural, and other issues. Media used for satire range from traditional literature (books, poems, drawings, pieces of music, etc) to more modern versions of expression (online articles, comics, memes, etc.).

The "evil" criticized by the previously presented online comics and memes is the aforementioned "ethnical, racial, and religious fanaticism" that the creators believe influences inter-society relations in a negative way. The "literature" of online comics and memes is representative of the prevalent fanaticism of the society. The meme creators tend to hint that Islamic fanaticism is an insult to Islam because it deviates from the original purpose of the religion, which was to deliver the message of peace (Santayana, 1905).

Another point the creators intend to deliver to their readers is the manner in which extremists on social media strengthen their arguments by cocoklogi or the art of justifying arguments by matchmaking ideas with ideas or ideas with occurrences (Suci, 2017) without proper scientific basis (Brotherton, 2015) and regardless of the truth. One of the issues discussed in the present study is the behavior of Islamic fanatics: a correlation exists between their identity as proclaimed Muslims and their justification of cocoklogi. To put identity matters into consideration, people tend to "act" in the name of identity under five circumstances: when their worldview (the ideal form of the world people with certain identity dream of) is under threat, when they intend to make a claim (justifying their existence in the world), when people of a certain identity sense that they are not recognized and respected, and when their identity is required due to changes that occur at the micro or macro social levels (Chryssochoou, 2003). It can be argued based on this perspective that Islamic radicals intend to protect their ideas and to gain followers and recognition at all costs, even if it means justifying their beliefs through cocoklogi.

The final message meme creators purpose to convey concerns the habit of blindly "liking and sharing" posts online (Akbar, 2019). The habit of spreading information without further assessment and is a popular trend among Internet users today. In fact, despite the increasing rates of digital literacy in many parts of the world including Indonesia (The Jakarta Post, 2018), people continuously complain about their relatives' and neighbors' lack of ability to critically assess what they read on social media platforms. Thus, ordinary users foster the spread of fake news without meaning to (Kurnia \& Astuti, 2017). Whitney Phillips' study suggested the existence of people's tendency to perform illogical actions and to make split-second decisions based on their intuitions and influenced by the popular worldview of a topic (Martineau, 2019). Therefore, the habit of blindly liking and sharing online information occcurs because people are irrational when they are faced with the news that suits their taste, whether it is fake or real.

\subsection{Playing the Game of Ethnic Jokes}

Jokes are a source of laughter and amusement (Ince, 2018), and have been a regular part of human life through its history. The art of telling a joke has been inherited by human civilizations. It takes place in myriad ways, from regular conversations between people to the modern form of standup comedy, and it appears that telling jokes or laughing at jokes causes stress to be relieved (Mattos, 2008).

The materials that make jokes are innumerable; as a matter of fact, almost everything can be transformed into jokes up to the point that it does not achieve a certain psychological barrier and is not funny anymore. Communities have always made jokes on topics such as cultural, social, political, or personal events, and more. Sections of communities often go so far as to make jokes for unusual or even unethical reasons: they make fun of aspects such as people's physical identities and conditions, their religions, the sexual inclinations and behaviors, and so on. It is common to helplessly observe that while jokes trigger an urge to laugh in some people, they may also upset others, and categories of jokes falling into this description may be considered to be "ethnic/sensitive." Researchers often criticize this type of evocation of laughter, or even the general habit of making jokes, arguing that jokes are deliberately crafted for ill intentions. Other scholars also argue that jokes are playful interpersonal interactions. However, there is a third view of jokes: a sensitive or ethic joke is "an ideal tool for the study of some of the subtle, pernicious, and sensitive aspects of intergroup behavior" (Hodson, Rush, \& MacInnis, 2010).

The trend of making jokes also applies to communities residing in Indonesia and Malaysia in which people make fun of each other within their or outside theie groups. The topics may vary from daily activities or funny accidents to basic aspects such as how one person differs from another. For some people, the joke is worth laughing because of its ridiculousness and is not to be taken seriously; for others, the joke can be an extremely serious and offensive message (Hodson, Rush, \& MacInnis, 2010). In the case of Indonesian and Malaysian communities, racial, ethnic, 
and religious aspects are often considered as aforementioned "ethnic/sensitive jokes." The general opinion is divided into two poles: one suggests that ethnic and sensitive jokes should be considered as "just jokes" and should never be taken into serious discussions; the other suggests that these three aspects are so sacred they should never be joked about. Religious experts, including Islamic scholars, are considerably concerned about whether or not to categorize ethnic/sensitive jokes as forbidden by Islam as humor of something is allowed as long as it follows these important aspects: not to lie; not to blashpeme any religious, racial, and ethnic identity; not to steal others' possession as a joke; not to scare people; not to spend time only in joking around; not to speak of issues forbidden by the religion; and not to joke too often (Marwan, 2013).

It appears that the creators of the exemplified online comics and memes in Indonesia and Malaysia are aware of this discussion and are thus creating their own sets of justifications. Despite clearly exploiting these three values (racial, ethnic, religious) as well as political issues and transforming them into humor, their argument is considerably sound: they do not mock the identities (religion, race, ethnic, politics); rather, they satirize the people who possess, implement, and enforce these values to the extent in which they become ridiculous. Despite seeming sensitive, the jokes are aware that these aspects, and particularly religion, are paramount for both Indonesians and Malaysians. Thus, they maintain a "borderline" that limits their jokes to extreme activities instead of the questioning of fundamental issues such as the characteristics that create such conduct (Alpantuni \& Renaldi, 2019).

\subsection{The Identical Sense of Humor in Indonesians and Malaysians}

Indonesian and Malaysian communities are considered by each other and by other communities around the globe as the "brothers who never stop fighting each other." Relations between the two countries have been in a continuous state of flux for decades: they befriend each other sometimes and harass each other at others over varied issues. While the state officials of both countries consider their associations to be positively inclined, the same cannot be said at the civil level. For instance, the repetitive negative news coverage regarding Indonesian migrant workers (Tenaga Kerja Indonesia/TKI) in Malaysia and their harassment by their employers (Hara, 2008) has angered Indonesians numerous times. In turn, the same fire is found in Malaysians when Indonesians chant Soekarno's "Ganyang Malaysia" Confrontation-era jargon in various sporting events (Clark \& Pietsch, 2014). However, despite the tensions between the two countries, there have also been times when they have worked together. A recent example is the "Crispy
Rendang" incident when Master Chef UK decided to eliminate a Malaysian-born contestant, Zaleha Kadir Olpin, for her preparation of chicken rendang commenting that it was "not crispy" and "cannot be eaten." This ouster caused massive Internet outbursts in Indonesia, Malaysia, Singapore, and Brunei Darussalam questioning the credibility of the judges (Agence France-Presse in Jakarta, 2018).

In facing the challenge of political differences, it appears that the citizens of both countries unconsciously construct a sense of belonging and interdependence between each other based on their identical historical, cultural, and familial ties. The ideas of interdependence (Indonesia and Malaysia are getting more dependent to each other), common fate (both were colonized by European powers), homogeneity (both have similar ancestry), and self-restraint (both refrain from committing any mischiefs) (Hara, 2008) are continuously propagated by officials of both states and by pro-friendship groups to promote positive IndonesiaMalaysia relations. Further, relations between Indonesia and Malaysia are not limited to bilateral ties but also to all ASEAN member states (Domínguez, 2015) along with the global market network distributing exportimport commodities through the Malaccan strait with approximately 50,000 vessels passing through it annually (Evers \& Gerke, 2006).

Among the values continuously promoted by the public is how the Indonesian and Malaysian sense of humor is identical (Raslan, 2010). It is relatively easy for Indonesians to understand the Malaysian sense of humor. They can commonly use Bahasa Melayu (Bahasa Malay), a language closely related to Bahasa Indonesia, and vice versa through mere weeks or months of adaptation. During interactions with each other, the two peoples generally share their humorous propensities, which tend toward self-experienced funny accidents, news headlines, gossip, and sports. The humor of university students may extend to class materials, campus life, and political issues. Often, they also make fun of how similar and different Bahasa Indonesia and Bahasa Malay can be. Like many communities around the world, both Indonesia and Malaysia possess their own versions of ethnic/sensitive jokes such as sexual innuendos, religious humor, ethnoracial jokes, etc. Among all topics, apparently, confrontation-era issues and TKI abuses are not included in their humor lists as both communities have constructed a subconscious mechanism of self-restraint to prevent unnecessary conflicts in their relationship (Hara, 2008).

\section{CONCLUSION}

Islamic fanaticism involves a long process of indoctrination by certain groups asserting their political and religious goals and accumulating supporters with or without consent. Additionally, racial and ethnic 
identification and their associations with religion are pivotal to the further enhancement of the extent of segregation within societies, and often ignite clashes in the process. It is unfortunate to observe that in countries with a Muslim majority, the conservative "education" process triggers unfavorable separations, even among Muslims, dividing moderate and conservative Muslim groups. inter-racial tensions have reached alarming levels in Indonesia and Malaysia amidst growing hostility toward moderate Muslims and minority groups and the misuse of social media, which is "bombed" by inter-religion hoaxes and hate content.

Concerned by this issue, several groups that are negatively affected by the phenomenon have begun to voice their apprehensions in rather "unusual" ways: the dissemination of humorous material through memes and online comics. These groups often present their ideas by referring to viral events that occur around the world and especially in their home countries. They represent these events through a series of pictures that can be either be funny or insulting. The authors of these online comics and memes apparently intend to deliver a satirical message to the public that Islamic fanatics exploit Islam for their personal interests and thus taint the value of Islam by spreading falsehood and disinformation that is exacerbated by the low digital literacy rates of the two countries. Despite targeting Islamic fanatics, the creators of the memes and cartoons are very aware of the importance and sacredness of religious, ethnic, and racial values for Indonesians and Malaysians. Hence, they do not cross boundaries and refrain from insulting any of the religious attributes; instead, their diatribes ridicule the activities undertaken by the fanatics. In addition, online comics and memes by Indonesian and Malaysian authors are relatively enjoyable for the public of both countries because of their shared languages and sense of humor.

\section{REFERENCES}

[1] 'BBC News Indonesia' 2019, April 2 Hoaks jelang pilpres meningkat, penebarnya 'kebanyakan kaum $i b u$. Retrieved from BBC News Indonesia. Retrieved from https://www.bbc.com/indonesia/indonesia$\underline{47769556 .}$.

[2] 'History' (2019). (Director). What Is Populism? | History [Motion Picture].

[3] 'Indonesia Bertauhid' 2016, December 30 Mana yang Jamaah Inginkan? Retrieved from hidupberkah.id on Instagram. Retrieved from https://www.instagram.com/p/BOob9bYh-YP/.

[4] 'meme'. $\quad$ Retrieved from https://www.facebook.com/meme.malaysian/.n.d., malaysia. meme.malaysia. Retrieved from Facebook.

[5] 'uruchanxxx' (2013, July 23). Just FPI. Retrieved from 1Cak. Retrieved from https://1cak.com/358365.

[6] Agence France-Presse in Jakarta 2018, April 3. 'I would rendang his head': UK MasterChef judges stir up a storm. Retrieved from The Guardian'. Retrieved from https://www.theguardian.com/tvand-radio/2018/apr/03/i-would-rendang-his-headuk-masterchef-judges-stir-up-a-storm.

[7] Akbar, C. 2019, April 1. 'Menjelang Pilpres, Kominfo: jumlah hoax akan terus melonjak'. Retrieved from Tempo.co. Retrieved from https://bisnis.tempo.co/read/1191304/menjelangpilpres-kominfo-jumlah-hoax-akan-terusmelonjak/full\&view=ok.

[8] alPantuni 2019, June 12. 'Kerancuan para Ustad. Retrieved from alPantuni on Instagram'. Retrieved from https://www.instagram.com/p/Bymitp7naOi/.

[9] Alpantuni and Renaldi, A. 2019, February 25. 'Pembuat komik gay Muslim di Instagram buka suara: aku tak berusaha menghina Agama. Retrieved from VICE Indonesia'. Retrieved from https://www.vise.com/id_id/article/vbwykd/pembu at-komik-gay-muslim-di-instagram-buka-suaraaku-tak-berusaha-menghina-agama.

[10] Amnesty International. (n.d.). 'Israel and occupied palestinian territories 2017/2018. Retrieved from Amnesty International'. Retrieved from https://www.amnesty.org/en/countries/middle-eastand-north-africa/israel-and-occupied-palestinianterritories/report-israel-and-occupied-palestinianterritories/.

[11] Beydoun, K. A. 2018 American Islamophobia: understanding the roots and rise of fear. University of California Press, CA.

[12] Bisyir, I. 2019, May. 'Stop ijin FPI'. Retrieved from Change.org. Retrieved from https://www.change.org/p/menteri-dalam-negeritjahjo-kumolo-stop-ijin-fpi?use react=false.

[13] Blow, C. M. 2019, June 5. 'It's all rooted in White panic. Retrieved from The New York Times'. Retrieved from https://www.nytimes.com/2019/06/05/opinion/whit e-supremacy-trump.html.

[14] Brotherton, R. (2015). 'Suspicious minds: why We believe conspiracy theories'. New York: Bloomsbury SIGMA. 
[15] Bulbulia, J. (2008). 'Meme infection or religious niche construction? An adaptationist alternative to the cultural Maladaptationist hypothesis'. Method and Theory in the Study of Religion, 20(1), pp. 67107. https://doi.org/10.1163/157006808X260241.

[16] Burroughs, B. and Feller, G. (2015). 'Religious memetics: institutional authority in digital/lived religion'. Journal of Communication Inquiry, 39(4), pp. 357-377. https://doi.org/10.1177/0196859915603096.

[17] Cahyono, E. 2018, October 22. 'Media sosial, post truth dan Literasi digital. Retrieved from Kantor Staf Presiden'. Retrieved from http://ksp.go.id/media-sosial-post-truth-danliterasi-digital/index.html.

[18] Chellaney, B. 2019, April 26. 'Asia the new Ground Zero for Islamist terror. Retrieved from Asia Times'. Retrieved from https://www.asiatimes.com/2019/04/opinion/asiathe-new-ground-zero-for-islamist-terror/.

[19] Chew, A. 2019, April 7. 'Let's copy Malaysia': fake news stokes fears for Chinese Indonesians. Retrieved from South China Morning Post'. Retrieved from https://www.scmp.com/weekasia/politics/article/3004909/indonesia-electionanti-beijing-sentiments-spread-will-chinese.

[20] Chryssochoou, X. (2003). 'Studying identity in social psychology: some thoughts on the definition of identity'. Journal of Language and Politics, pp. 225-241.

[21] Clark, M. and Pietsch, J. 2014 Indonesia-Malaysia relations: cultural heritage, politics and labour migration. Routledge, Oxon.

[22] CNN Indonesia 2019, May 22. 'Media Asing Soroti 'Kerusuhan' dan 'Kekerasan' Demo 22 mei. Retrieved from CNN Indonesia'. Retrieved from https://www.cnnindonesia.com/internasional/20190 522095855-106-397250/media-asing-sorotikerusuhan-dan-kekerasan-demo-22-mei.

[23] Colas, D. 1997 Civil society and fanaticism: conjoined histories. Stanford University Press, Stanford, CA.

[24] Comic Islam, M. 'Meme Comic Islam. Retrieved from Facebook'. Retrieved from https://www.facebook.com/MCIslam/?epa=SEAR CH_BOX.

[25] Dennett, D. C. (1998). 'The evolution of religious memes: Who-or what-benefits?' Method and Theory in the Study of Religion, 10(1), pp. 115128. https://doi.org/10.1163/157006898X00394
[26] Domínguez, G. 2015, June 2. 'Improved IndonesiaMalaysia ties 'significant' for ASEAN. Retrieved from DW'. Retrieved from https://www.dw.com/en/improved-indonesiamalaysia-ties-significant-for-asean/a-18237917.

[27] Dopesmoker 2017, March 10. 'Just throw it. Retrieved from Know Your Meme'. Retrieved from https://knowyourmeme.com/photos/1231061islam.

[28] Durkheim, E. (1915). 'The elementary forms of religious life' London: G. Allen \& Unwin.

[29] Durohman, I., F., G. A. and Rizal, M. 2017, July 27. 'Edisi terakhir media propaganda HTI. Retrieved from DetikX'. Retrieved from https://x.detik.com/detail/investigasi/20170727/Edi si-Terakhir-Media-PropagandaHTI/index.php?tag from=news bacaJuga.

[30] Evers, H. E. and Gerke, S. (2006). 'The strategic importance of the Straits of Malacca'. SSRN Electronic

Journal. https://doi.org/10.2139/ssrn.1020877.

[31] Farzan, A. N. 2019, March 18. 'Fraser Anning, egged after mosque attacks, may be Australia's most reviled politician. Retrieved from The Washington Post'. Retrieved from https://www.washingtonpost.com/nation/2019/03/1 8/fraser-anning-egged-after-mosque-attacks-maybe-australias-most-reviledpolitician/?utm term $=.23 \mathrm{ff} 0843089 \mathrm{~b}$.

[32] Fitriyah, L. 2016, October 15. 'Indonesian Muslims' religious arrogance. Retrieved from The Jakarta Post'. Retrieved from https://www.thejakartapost.com/academia/2016/10/ 15/indonesian-muslims-religious-arrogance.html.

[33] Gallup. 'Islamophobia: understanding anti-Muslim sentiment in the west. Retrieved from Gallup'. Retrieved from https://news.gallup.com/poll/157082/islamophobiaunderstanding-anti-muslim-sentiment-west.aspx.

[34] Gil, P. 2019, May 6. 'What is a meme? Retrieved from LifeWire'. Retrieved from https://www.lifewire.com/what-is-a-meme2483702.

[35] Hara, A. E. 2008. 'Hubungan Malaysia dan Indonesia: dari Saudara Serumpun ke 'Smart Partnership'?' International conference IndonesiaMalaysia update, 2008.

[36] Hasan, N. (2011). 'Political Islam in Indonesia'. Politics of Religion in South and Southeast Asia, pp. 136-156. 
[37] Hodgart, M. J. 2010 Satire: origins and principles. Transaction Publishers, NJ.

[38] Hodson, G., Rush, J. and MacInnis, C. C. (2010). 'A joke is just a joke (except when it isn't): cavalier humor beliefs facilitate the expression of group dominance motives'. Journal of Personality and Social Psychology, 99(4), pp. 660-682. https://doi.org/10.1037/a0019627.

[39] Hudson, M. 2019, May 8. 'What is social media? Retrieved from The Balance Small Business'. Retrieved from https://www.thebalancesmb.com/what-is-socialmedia-2890301.

[40] Huntington, S. P. 1996 The Clash of civilizations and the remaking of world order. Simon \& Schuster, New York City.

[41] Ince, R. 2018 I'm a joke and so are You: reflections on humour and humanity. Atlantic Books, London.

[42] Islam, M. 2017, November 24. 'Indonesia' Yuk Kita Saling mengajak kebaikan. Retrieved from Meme Islam Indonesia on Facebook. Retrieved from

https://www.facebook.com/adhehariTV/photos/a.9 38114083005943/939638309520187/?type $=3 \&$ the ater.

[43] Islam, M. (2017, June 4). 'Indonesia'. Nunggu Gini Dulu Baru Kemasjid? Retrieved from Meme Islam Indonesia on Facebook. Retrieved from https://www.facebook.com/adhehariTV/photos/a.8 $28604903956862 / 840774456073240 /$ type $=3 \&$ the ater.

[44] Jazeera, A. 2019, March 17. 'A summary of attacks on Muslims in Western countries. Retrieved from Al Jazeera'. Retrieved from https://www.aljazeera.com/news/2019/03/summary -attacks-muslims-western-countries190316150024125.html.

[45] KOSTUM 2019, March 19. 'KOSTUM (komik strip untuk umum). Retrieved from KOSTUM (komik strip untuk umum) on Facebook'. Retrieved from

https://www.facebook.com/KOSTUMKOMIK/pho tos/a.10152007377757654/10156276382947654/?t ype $=3 \&$ theater.

[46] KOSTUM 2019, March 23. 'KOSTUM (komik strip untuk umum). Retrieved from KOSTUM (komik strip untuk umum) on Facebook'. Retrieved from

https://www.facebook.com/KOSTUMKOMIK/pho tos/a.10152007377757654/10156284852007654/?t ype $=3 \&$ theater.
[47] Kurlantzick, J. 2018, February 27. 'The rise of Islamist groups in Malaysia and Indonesia. Retrieved from Council on Foreign Relations'. Retrieved from https://www.cfr.org/expertbrief/rise-islamist-groups-malaysia-and-indonesia.

[48] Kurnia, N. and Astuti, S. I. 2017, September 25. 'Researchers find Indonesia needs more digital literacy education. Retrieved from The Conversation'. Retrieved from http://theconversation.com/researchers-findindonesia-needs-more-digital-literacy-education$\underline{84570 .}$.

[49] Liow, J. C. and Tan, J. 2019, May 17. 'May 13, 1969 - the ghost that still haunts Malaysia. Retrieved from The Straits Times'. Retrieved from https://www.straitstimes.com/opinion/may-131969-the-ghost-that-still-haunts-malaysia.

[50] Madinier, R. (2011). 'The Catholic politics of inclusiveness: A Jesuit epic in Central Java in the early twentieth century and its memory'. Politics of Religion in Indonesia: Syncretism, Orthodoxy, and Religious Contention in JAVA and Bali, pp. 23-47.

[51] Martineau, P. 2019, August 22. 'Why people keep falling for viral hoaxes. Retrieved from WIRED'. Retrieved from https://www.wired.com/story/whypeople-keep-falling-viral-hoaxes/.

[52] Marwan, I. (2013). 'Rasa Humor dalam Perspektif Agama' Al-Turāś, 267-278.

[53] Mattos, R. 2008 California highway patrol. Arcadia Publishing, San Fransisco.

[54] Me.me. 2017, March 26. 'Traditional dress in countries uniform Before an Islamic Revolution dress'. Retrieved from Me.me. Retrieved from https://me.me/i/raditional-dress-in-countriesuniform-before-an-islamic-revolution-dress11991500

[55] Me.me. 2017, July 24. 'Tak share status pasal kejadian al Aqsa di Palestin'. Retrieved from Me.me. Retrieved from https://me.me/i/tak-sharestatus-pasal-kejadian-alaosaidi-palestin-gagsmalaysia-oranganggapkita-17571248.

[56] Mina, A. X. 2019 Memes to movements: how the world's most viral media is changing social protest and power. Beacon Press, Boston.

[57] Mohamad, M. (2011). 'Creating a Muslim majority in plural Malaysia: undermining minority and women's rights'. Politics of Religion in South and Southeast Asia, pp. 174-194.

[58] Mountaine 2019, June 8. 'China apa Islam? Retrieved from Mana Saya Tau Saya Kan Pencurry 
7.0 on Facebook'. Retrieved from https://www.facebook.com/MSTSKP7.0/photos/a.3 $\underline{67150247206132 / 411589842762172 / \text { ?type }=3 \& \text { the }}$ ater.

[59] Muslim Memes, S. L. 2019, January 28. 'SL Muslim memes. Retrieved from SL Muslim Memes on Facebook'. Retrieved from https://www.facebook.com/SLMuslimMemes/phot os/a.863145613862879/1134722886705149/?type= 3\&theater.

[60] Osman, M. N. M. (2017). 'The Islamic conservative turn in Malaysia: impact and future trajectories'. Cont. Islam, 11(1), 1-20. https://doi.org/10.1007/s11562-016-0373-3.

[61] Pariona, A. 2018, August 15. 'Religious demographics of Southeast Asia. Retrieved from World Atlas'. Retrieved from https://www.worldatlas.com/articles/religiousdemographics-of-southeast-asian-nationsdependent-territories.html.

[62] Picard, M. (2011). 'Introduction: 'Agama', 'adat', and Pancasila'. Politics of Religion in Indonesia: Syncretism, Orthodoxy, and Religious Contention in JAVA and Bali, pp. 1-20.

[63] Prakash, B. 2002 Sociolegal status of women in Indonesia. Regional and Sustainable Development Department Asian Development Bank, MALAYSIA, PHILIPPINES, AND THAILAND.

[64] Raslan, K. (2010) Ceritalah Indonesia. [Jakarta: Kepustakaan populer Gramedia].

[65] Reuters 2019, March 12. In Muslim. 'Malaysia, uproar over LGBTQ groups at Women's Day march. Retrieved from NBC News'. Retrieved from https://www.nbcnews.com/feature/nbcout/muslim-malaysia-uproar-over-lgbtq-groupswomen-s-day-march-n981751.

[66] Ridwan, M. 2018, February 24. 'Mengenang peristiwa bom bali 2002, Memendam cerita demi sang buah hati'. Retrieved from JawaPos.com. Retrieved from https://www.jawapos.com/features/24/02/2018/me ngenang-peristiwa-bom-bali-2002-memendamcerita-demi-sang-buah-hati/.

[67] Robinson, G. and Roughneen, S. 2017, December 13. 'Religious extremism poses threat to ASEAN's growth. Retrieved from Nikkei Asian Review'. Retrieved from https://asia.nikkei.com/Spotlight/CoverStory/Religious-extremism-poses-threat-toASEAN-s-growth2.
[68] Roughneen, S. 2017, December 13. 'Ugly social media wars fueling intolerance in Asia. Retrieved from Nikkei Asian Review'. Retrieved from https://asia.nikkei.com/Politics/Ugly-social-mediawars-fueling-intolerance-in-Asia.

[69] Santayana, G. 1905 The life of reason or the phases of human progress. Charles Scribner's Sons, New York.

[70] Saputra, A. 2019, February 15. 'Tok! MA Sahkan Pembubaran HTI'. Retrieved from Detik.com. Retrieved from https://news.detik.com/berita/d4430074/tok-ma-sahkan-pembubaran-hti.

[71] Suci, A. 2017 Nubuat Petaka akhir zaman. Wahyu Qolbu, Jakarta.

[72] Susetio, J. 2018, June 7. 'Ketua Bawaslu Sumut Safrida Tanggapi Spanduk Larangan memilih pemimpin Kafir'. Retrieved from TribunMedan.com. Retrieved from https://medan.tribunnews.com/2018/06/07/ketuabawaslu-sumut-safrida-tanggapi-spanduk-laranganmemilih-pemimpin-kafir?page=all.

[73] Tan, S. 2017, September 27. 'Wahhabi Wannabes and Malaysia's moderate Muslim myth. Retrieved from Hoover Institution'. Retrieved from https://www.hoover.org/research/wahhabiwannabes-and-malaysias-moderate-muslim-myth. Stanford University.

[74] Teruelle, R. 2011. 'Social media and youth activism', In HS Al-Deen \& JA Hendricks. Usage and Impact, Social Media. Lexington Books, Plymouth (201-217).

[75] The Jakarta Post 2018, February 20. 'Internet literacy reaches more than half of Indonesian population: survey. Retrieved from The Jakarta Post'. Retrieved from https://www.thejakartapost.com/life/2018/02/20/int ernet-literacy-reaches-more-than-half-ofindonesian-population-survey.html.

[76] von Hein, M. 2017, September 7. 'Saudi Arabia exports extremism to many countries - including Germany, study says. Retrieved from DW'. Retrieved from https://www.dw.com/en/saudiarabia-exports-extremism-to-many-countriesincluding-germany-study-says/a-39618920.

[77] Vulpineninja 2015, June 17. 'Ramadhan baru je mula tapi aku masih nak cari pasal kan? Retrieved from Vulpineninja on Facebook'. Retrieved from https://www.facebook.com/vulpineninja/photos/a.4 49885075106708/812023155559563/?type=3\&the ater. 
[78] Vulpineninja 2019, April 2. 'Commissioned by anonymous. Retrieved from Vulpineninja on Facebook'. Retrieved from https://www.facebook.com/vulpineninja/photos/a.8 09328752495670/2057635634331636/?type $=3 \&$ th eater.

[79] Wiggins, B. E. 2019 The discursive power of memes in digital culture: ideology, semiotics, and intertextuality. Routledge, London.
[80] Wijaya, P. 2018, December 12 Demo, 812 'di Malaysia, Negeri Jiran Masih Dibekap Isu Diskriminasi Ras'. Retrieved from Merdeka.com. Retrieved from https://www.merdeka.com/dunia/demo-812-dimalaysia-negeri-jiran-masih-dibekap-isudiskriminasi-ras.html. 